\title{
KEPEMIMPINAN PARTISIPATIF, BUDAYA KERJA, DAN PENGARUHNYA TERHADAP KINERJA PEGAWAI UNIVERSITAS NEGERI YOGYAKARTA
}

\author{
Sunarta, Wuradji \\ Fakultas Ekonomi UNY, Universitas Negeri Yogyakarta \\ sunarta_tni@yahoo.com,
}

\begin{abstract}
Abstrak
Penelitian ini bertujuan untuk mengetahui: pengaruh kepemimpinan, budaya kerja, dan motivasi kerja terhadap kinerja pegawai di lingkungan Universitas Negeri Yogyakarta. Sampel ditentukan menggunakan teknik proportionate stratified random sampling. Jumlah sampel dari unsur dosen sebanyak 260 orang, unsur administrasi 220 orang, dan unsur mahasiswa 320 orang. Data dikumpulkan menggunakan angket dan dianalisis menggunakan Regresi Sederhana dan Regresi Ganda dengan bantuan software SPSS Versi 17.0. Hasil penelitian pada taraf signifikansi 5\% menunjukkan: (1) kepemimpinan partisipatif

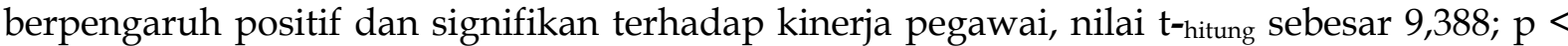
0,05 dan $\mathrm{R}^{2}=0,419$; (2) budaya kerja berpengaruh positif dan signifikan terhadap kinerja, nilai t-hitung sebesar 6,167; < 0,05 dan $\mathrm{R}^{2}=0,224$; (3) motivasi kerja berpengaruh positif dan signifikan terhadap kinerja, nilai t-hitung sebesar 6,261; $\mathrm{p}<0,05$ dan $\mathrm{R}^{2}=0,265$; dan (4) secara bersama-sama kepemimpinan, budaya kerja, dan motivasi kerja berpengaruh positif dan signifikan terhadap kinerja, nilai F-hitung sebesar 98,432; $\mathrm{p}<0,05$ dan $\mathrm{R}^{2}=0,589$.
\end{abstract}

Kata kunci: kepemimpinan partisipatif, budaya kerja, motivasi, dan kinerja

\section{THE PARTICIPATIVE LEADERSHIP, WORKING CULTURE, AND THEIR EFFECTS ON THE WORKING PERFORMANCE OF THE STAFF OF YOGYAKARTA STATE UNIVERSITY}

Abstract
This research is aims to reveal influence of the leadership, working culture, and working motivation all together on the working performance of the staff of Yogyakarta State University. The sample was established utilizing the proportionate stratified random sampling technique. The sample consiststed of 260 lecturers, 220 administration affair staffs and 320 students. The data were collected using a questionnaire and analyzed using the simple and multiple regressions by using SPSS software 17.0 version. The findings of the research within the significance level of 5\% show that (1) the participative leadership gives a positive and significant effect on the working performance of the staff as proved by 9,388 $t$ [count]; $p<0,05$ significance and $R^{2}=0,419$; (2) the working culture gives positive and significance effect on working performance of the staff as proved by $6.167 t$ [count]; $p<$ 0.05 significance and $R^{2}=0,224$; (3) the working motivation gives a positive and significant effect on the working performance of the staff as proved by $6.261 t$ [count]; $p<0,05$ significance and $R^{2}=$ 0,265; and (4) the participative leadership, working culture, and working motivation all together give a positive and significant effect on the working performance of the staff as proved by 98,432 F [count]; $p<0.05$ and $R^{2}=0,589$.

Keywords: participative leadership, working culture, motivation and working performance. 


\section{Pendahuluan}

Seiring dengan perkembangan teknologi dan informasi yang begitu pesat, organisasi yang ingin meraih kinerja tinggi membutuhkan pegawai profesional dan kompeten di bidangnya. Organisasi yang tidak bisa memenuhi tuntutan tersebut akan mengalami kesulitan dalam mempertahankan dan mengembangkan eksistensinya. Kemajuan dan kecanggihan teknologi yang tidak diimbangi dengan ketersediaan pegawai yang memiliki keterampilan dan keahlian di bidangnya akan berdampak pada tingkat capaian kinerja yang diinginkan.

Dalam praktik kerja sehari-hari, semangat kerja yang tinggi berpengaruh terhadap capaian kinerja secara individu maupun organisasi. Semangat kerja tinggi yang ditunjukkan oleh pegawai perlu diimbangi dengan penciptaan iklim kerja yang kondusif sehingga dalam jangka yang panjang dapat membentuk budaya kerja yang mendukung tercapainya kinerja organisasi. Organisasi yang berhasil ditunjukkan oleh capaian kinerja yang dihasilkan oleh para pegawai yang kompeten, berdaya, dan bekerja dalam lingkungan yang kondusif di bawah kendali pemimpin yang kompeten.

Pada kondisi tingkat kepuasan mengalami penuruan yang berdampak pada menurunnya kinerja pegawai sebagai, maka dibutuhkan sosok pemimpin yang mampu menggerakkan semangat bawahan ke arah yang lebih baik. Melalui paradigma baru, pemimpin sebagai agen perubahan (agent of change), maka pemimpin sebenarnya memiliki posisi strategis dalam memotivasi, memajukan, dan memberdayakan pegawai. Seorang pemimpin merupakan figur atau referensi yang dianut dan dicontoh dalam segala hal bagi para pegawai yang menjadi bawahannya. Dengan kata lain seorang pemimpin harus bisa mengarahkan apa yang menjadi visi, misi, dan tujuan organisasi agar diperoleh kinerja yang tinggi.

Kinerja menurut Sinambela (2012, p.5) adalah "pelaksanaan suatu pekerjaan dan penyempurnaan pekerjaan sesuai de- ngan tanggung jawab sehingga mencapai hasil sesuai dengan yang diharapkan". Definisi di atas mengindikasikan bahwa kinerja dipandang sebagai hasil. Sementara jika kinerja yang diorientasikan pada sebuah proses, maka menurut Richard \& Murphy (Sudarmanto 2009, p.8) menyatakan bahwa "kinerja merupakan seperangkat perilaku yang relevan dengan tujuan organisasi atau unit organisasi tempat orang bekerja". Seperangkat perilaku yang relevan dengan organisasi di sini dapat dimaknai sebagai bentuk peraturan, norma-norma, nilai-nilai, dan kesepakatan tentang tata cara/prosedur kerja dalam melayani/ memuaskan pelanggan.

Pemimpin adalah sosok yang dijadikan panutan dan ukuran para bawahan di dalam berpikir, berperilaku, berbudaya, bersikap, dan berkomitmen. Dalam upaya mencapai tujuan organisasi, peran pemimpin adalah mengarahkan para bawahan dalam mewujudkan kepada tujuan-tujuan yang telah ditentukan. Seberapa baik kualitas seorang pemimpin di dalam kepemimpinannya, akan ditunjukkan oleh caranya melakukan pengarahan dan mendelegasikan wewenang yang dimiliki kepada para bawahannya.

Tujuan penelitian ini adalah untuk mengetahui: (1) ada tidaknya pengaruh kepemimpinan terhadap kinerja pegawai, (2) ada tidaknya pengaruh budaya kerja terhadap kinerja pegawai, dan (3) ada tidaknya pengaruh secara bersama-sama kepemimpinan dan budaya kerja terhadap kinerja pegawai di lingkungan Universitas Negeri Yogyakarta.

\section{Kepemimpinan}

Sampai saat ini, definisi tentang kepemimpinan oleh sebagian ahli dianggap sebagai suatu kotak hitam (black box) yang tabir misterinya belum bisa terungkap. Setiap ahli mempunyai definisi masing-masing tentang kepemimpinan, sehingga dapat dikatakan bahwa banyaknya definisi kepemimpinan jumlahnya sama dengan orang yang mendefinisikannya. Menurut Hughes, Ginnett \& Curphy (2006, 
p.6), menyebutkan bahwa "leadership is a complex phenomenon involving the leader, the followers, and the situation". Kepemimpinan adalah sebuah fenomena kompleks yang melibatkan pemimpin, pengikut, dan situasi. Pengertian kepemimpinan juga diberikan oleh Beerel (2010, p.64) yang menyatakan bahwa "leadership is relational activity where an in-dividuals guide or direct others (followers) to attain an objective or goal".

Sejalan dengan definisi di atas, Yukl (2006, p.10) juga melengkapinya dengan menyebutkan bahwa "leadership is the process of influencing others to understand and agree about what need to be done and how to do it, and the process of facilitating individual and collective efforts to accomplish shared objectives". Kepemimpinan adalah proses mempengaruhi orang lain untuk mengerti dan menyetujui tentang apa yang perlu dilakukan dan bagaimana melakukannya, dan proses untuk memfasilitasi upaya individu dan kolektif untuk mencapai tujuan bersama.
Kemudian menurut Bass (2008, p.25), menyatakan bahwa "leadership is an interaction between two or more members of a group that often involves a structuring or restructuring of the situation and of the perception and expectations of the members". Kepemimpinan merupakan interaksi antara dua atau lebih anggota kelompok yang sering terlibat dalam penataan atau penataan kembali atas situasi dan persepsi dan harapan para anggota.

Dari berbagai ragam definisi tentang kepemimpinan yang ada, pada dasarnya kepemimpinan menurut Triantoro Safaria (2004, p.4) mengandung beberapa unsur pokok antara lain: (1) pengaruh, (2) perubahan/proses, (3) tanggung jawab pribadi, (4) keinginan/nilai, (5) pengikut individu/kelompok, dan (6) tujuan/sasaran. Untuk mempermudah dalam memahami tentang enam unsur pokok kepemimpinan tersebut, dapat ditampilkan pada Gambar 1 berikut ini.

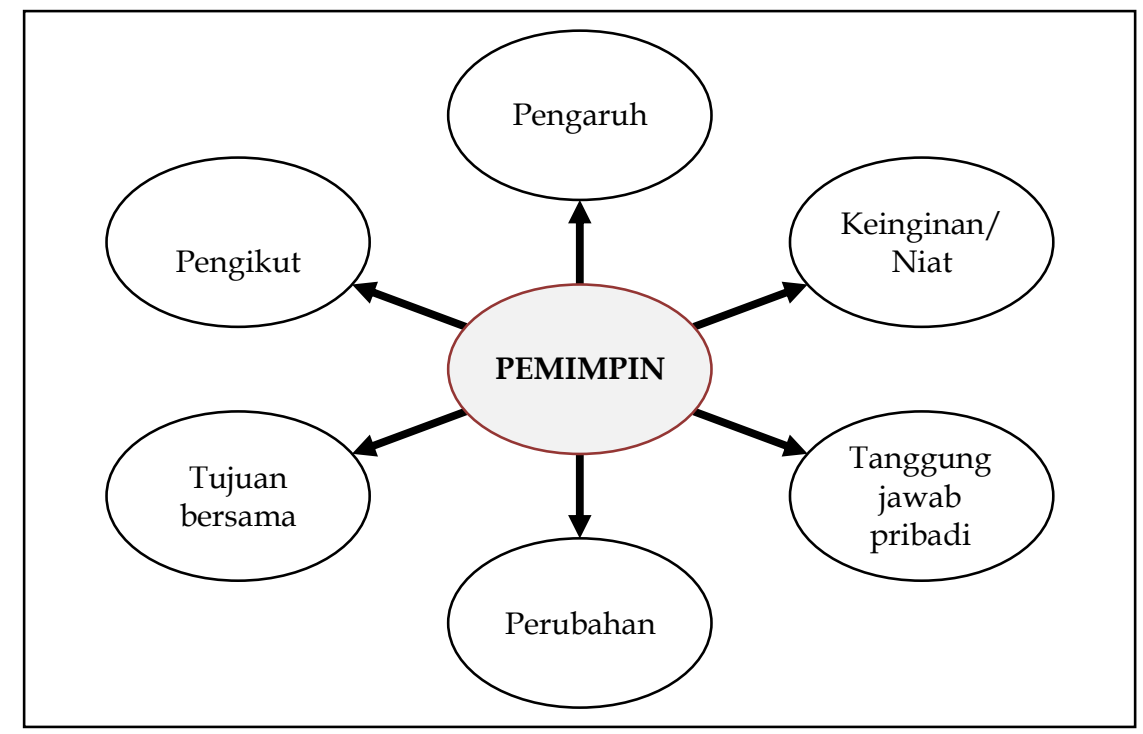

Sumber: Triantoro Safaria, (2004, p. 4)

Gambar 1. Unsur-Unsur Pokok Kepemimpinan

Pada gambar 1 di atas dapat dijelaskan bahwa seorang pemimpin dalam menjalankan kepemimpinannya melibatkan unsur pengaruh pribadi dalam mengajak para pengikut/bawahan dalam mencapai tujuan bersama yang dilandasi oleh semangat untuk berubah menuju yang lebih baik daripada sebelumnya. Dalam mewujudkan tujuan bersama, pemimpin dan pengikut saling terlibat aktif sebagai bentuk tanggung jawab pribadi (personal responsibility) untuk mencapai tujuan dan keinginan yang telah ditetapkan sebelumnya. 


\section{Budaya Kerja}

Definisi tentang budaya organisasi yang merupakan bentuk lain dari budaya kerja yang dikemukakan oleh Robin (2001, p.510) yang mengatakan bahwa "organization culture refers to a system of shared meaning held by members that distinguishes the organization from other organizations". Budaya organisasi mengacu pada sistem makna bersama yang diselenggarakan oleh anggota yang membedakan organisasi dengan organisasi lain. Lebih lanjut Robin menegaskan bahwa budaya kerja dapat dipersepsikan secara umum oleh para anggota pendukung organisasi dalam bentuk: identitas, kegiatan/aktivitas para anggota, perhatian atas kinerja anggota, kontrol atas perilaku yang bersifat ketat atau relatif bebas untuk berinisiatif, dan pandangan lainnya.

Kemudian budaya organisasi oleh Hoy \& Miskel (2008, p.177) juga dinyatakan bahwa "organization culture is a system of shared orientations that hold the unit together and give it a distinctive identitiy". Secara kontekstual dapat dimaknai bahwa budaya organisasi adalah suatu sistem orientasi bersama yang membentuk unit bersamasama sehingga memberikan identitas yang khas. Identitas khas pada suatu organisasi yang dibentuk melalui hubungan kerja sehari-hari para anggota, merupakan simbol-simbol nilai kebersamaan yang membedakan dengan organisasi lain sehingga tercipta suatu budaya kerja.

Menurut Wibowo (2012, p.15)

"Budaya terbentuk dari sekelompok orang terorganisasi yang mempunyai tujuan, keyakinan dan nilai-nilai yang sama, dan dapat diukur melalui pengaruhnya pada motivasi". Organisasi yang beranggotakan orang-orang dengan tujuan tertentu dalam berinteraksi satu sama lain dapat membentuk kebiasaan dan ikatan bersama an- tara individu dengan individu dan individu dengan kelompok. Melalui berbagai aktivitas yang diciptakan oleh para pemimpin sebagai sosok atau figur yang menaungi berbagai kepentingan, pemimpin berperan besar dalam pembentukan budaya.

Dalam kehidupan organisasi, proses pembentukan budaya organisasi dimulai karena adanya interaksi antara pemimpin dengan individu/kelompok. Sebagai bentuk aktivitas interaksi tersebut memunculkan berbagai gagasan/ide yang ditransformasikan menjadi artefak, nilainilai, dan asumsi. Bentuk implementasi dari artefak, nilai-nilai, dan asumsi tersebut yang menyebabkan terbentuknya sebuah budaya organisasi. Kekuatan budaya yang dibentuk bersama dan berfungsi sebagai perekat antaranggota organisasi, sangat ditentukan oleh seluruh elemen organisasi dalam merawat serta menjaga kelangsungan hidup budaya yang dianut bersama.

Menurut Sashkin \& Molly (2012, p.126) untuk membangun budaya, ada tiga cara/strategi yang bisa dilakukan pemimpin dalam praktik kepemimpinan. Pertama, para pemimpin (dengan keterli-batan orang lain) mendefinisikan sebuah filosofi organisasi secara eksplisit, jelas, dan merupakan pernyataan ringkas tentang nilai dan keyakinan. Kedua, para pemimpin itu bekerja dengan orang lain untuk menentukan berbagai kebijakan, mengembangkan berbagai program, dan menetapkan beberapa prosedur, yang membuat filosofi itu menjadi suatu tindakan nyata. Ketiga, para pemimpin mencontohkan berbagai nilai dan keyakinan lewat tindakan-tindakan mereka pada setiap kesempatan dan mereka mempraktikkannya secara konsisten.

Secara sederhana uraian tentang proses pembentukan budaya tersebut disajikan pada Gambar 2. 


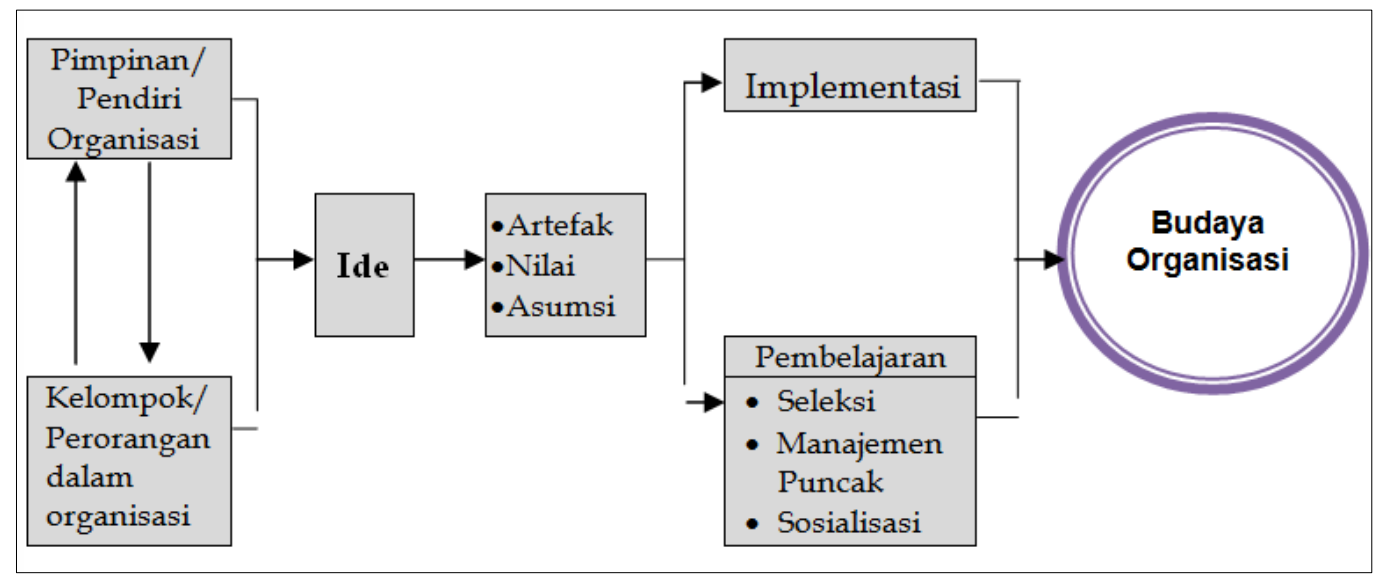

Gambar 2. Pembetukan Budaya Organisasi

Seperti yang disajikan pada gambar di atas, pada dasarnya budaya ada dan eksis di tengah-tengah kehidupan organisasi karena dilahirkan oleh inisiasi para pemimpin atau pendiri suatu organisasi. Peranan penting seorang pemimpin dalam suatu organisasi sangat menentukan dalam pembentukan dan penciptaan sebuah budaya dalam organisasi. Secepat dan sekuat apa budaya organisasi dapat berkembang dan dianut oleh seluruh anggotanya, sangat dipengaruhi oleh seberapa kuat seorang pemimpin dalam mengarahkan anggota untuk mematuhi budaya yang dibentuk tersebut.

\section{Kinerja}

Menurut Veithzal Rivai \& Ella Jauvani Sagala (2011, p.549), kinerja diberi pengertian "sebagai perilaku nyata yang ditampilkan setiap orang sebagai prestasi kerja yang dihasilkan oleh karyawan sesuai dengan perannya dalam perusahaan". Pengertian tersebut dapat dimaknai bahwa karyawan yang bekerja sesuai peran dan fungsinya dalam suatu organisasi akan menghasilkan prestasi kerja melalui serangkaian proses perilaku antara orang yang satu dengan yang lain. Dengan demikian kinerja juga dapat dimaknai sebagai sesuatu yang benar-benar dilakukan orang dalam organisasi yang dapat diamati oleh orang lain.

Kinerja dapat dipandang sebagai sebuah proses dan dapat pula dilihat sebagai suatu hasil. Kinerja yang pengertiannya menggunakan pendekatan pada pro- ses menanyakan aspek "apa" dan "bagaimana". Tentang apa yang dilakukan dalam bekerja, sebenarnya merujuk pada maksud sebaik apa pegawai dalam memberikan pelayanan kerja dan bagaimana cara melakukannya. Sementara kinerja yang berorientasi pada hasil lebih menanyakan pada aspek "berapa" dan "kapan". Aspek berapa merujuk pada makna jumlah atau kuantitas dan kapan merujuk pada pengertian waktu penyelesaian pekerjaan yang dilakukan pegawai.

Melalui definisi dan uraian tentang kinerja di atas, dapat disimpulkan bahwa sebenarnya kinerja adalah sesuatu yang dapat dilihat atau diamati. Perbedaannya adalah jika kinerja yang merujuk sebagai hasil dapat dilihat melalui kuantitas suatu produk/barang dalam unit tertentu. Kemudian kinerja yang merujuk sebagai perilaku dapat dilihat melalui pengamatan atau observasi yang bersifat kualitatif. Perilaku orang atau pegawai dalam bekerja dapat berupa tindakan, ucapan, sikap, dan perilaku yang sesuai de-ngan tujuan dan misi organisasi.

Untuk menilai tingkat capaian kinerja pegawai dalam suatu organisasi dalam dimensi hasil, ada beberapa indikator yang digunakan sebagai ukuran. Sedikitnya ada enam kriteria dasar dimensi untuk mengukur kinerja menurut Bernardin (Sudarmanto, 2009, p.12), yaitu: Pertama quality terkait dengan proses atau hasil mendekati sempurna/tidak dalam memenuhi maksud atau tujuan. Kedua quantity terkait dengan satuan jumlah atau kuan- 
titas yang dihasilkan. Ketiga timeliness terkait dengan waktu yang diperlukan dalam menyelesaikan aktivitas atau menghasilkan produk. Keempat costeffectiveness terkait dengan tingkat penggunaan sumber-sumber organisasi (orang, uang, material, teknologi) dalam mendapatkan atau memperoleh hasil atau pengurangan pemborosan dalam penggunaan sumber-sumber organisasi. Kelima need for supervision terkait dengan kemampuan individu dalam menyelesaikan pekerjaan atau fungsifungsi pekerjaan tanpa asistensi pimpinan atau intervensi pengawasan pimpinan. Keenam interpersonal impact terkait dengan kemampuan individu dalam meningkatkan perasaan harga diri, keinginan baik, dan kerja sama di antara sesama pekerja dan anak buah.

Sedangkan untuk mengukur kinerja dalam dimensi kualitas, menurut Parasuraman, Zeithamel \& Berry (Sudarmanto, 2009, p.14), ada sepuluh kriteria. Pertama keandalan, yakni mencakup konsistensi kinerja dan kehandalan dalam pelayanan: akurat, benar, dan tepat. Kedua daya tanggap, yaitu keinginan dan kesiapan para pegawai dalam menyediakan pelayanan dengan tepat waktu. Ketiga kompetensi, yaitu keahlian dan pengetahuan dalam memberikan pelayanan. Keempat akses, pelayanan yang mudah diakses oleh pengguna layanan. Kelima kesopanan, yaitu mencakup kesopansantunan, rasa hormat, perhatian, dan bersahabat dengan pengguna layanan. Keenam komunikasi, yaitu kemampuan menjelaskan dan menginformasikan pelayanan kepada pengguna layanan dengan baik dan dapat dipahami dengan mudah. Ketujuh kejujuran, yaitu mencakup kejujuran dan dapat dipercaya dalam memberikan layanan kepada pelanggan. Kedelapan keamanan, yaitu mencakup bebas dari bahaya, keamanan secara fisik, risiko, aman secara finansial. Kesembilan pengetahuan terhadap pelanggan, yaitu berusaha mengetahui kebutuhan pelanggan, belajar dari persyaratan-persyaratan khusus pe-langgan. Kesepuluh bukti langsung, meliputi fasilitas fisik, penampilan pegawai, peralatan, perlengkapan dan pelayanan.

\section{Kerangka Pikir dan Hipotesis}

Dalam penelitian ini terdiri dari tiga variabel bebas (independent variables) yakni kepemimpinan partisipatif, budaya kerja, motivasi kerja, dan variabel terikatnya (dependent variable) adalah kinerja. Secara skematis paradigma penelitian yang digunakan untuk mengetahui pengaruh antarvariabel tersebut dapat disajikan pada Gambar 2.

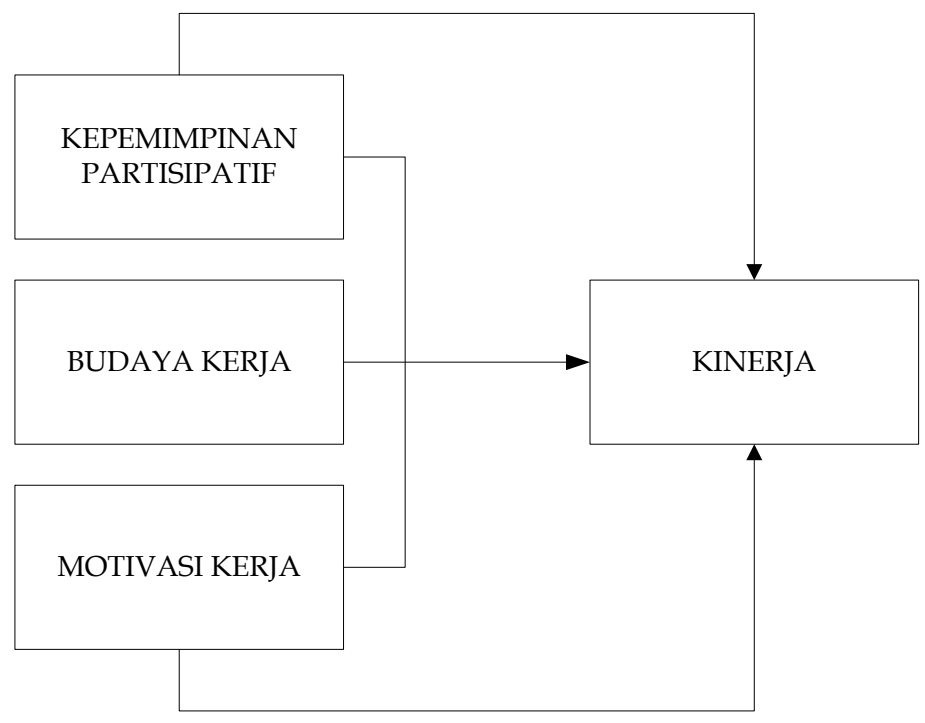

Gambar 3. Hubungan Variabel Ganda Dua Variabel Independen 
Sesuai dengan kerangka dan teoriteori yang telah dipaparkan seperti di atas, ada tiga hipotesis yang diajukan, (1) Ada pengaruh positif kepemimpinan partisipatif terhadap kinerja pegawai, (2) Ada pengaruh positif budaya kerja terhadap kinerja pegawai, (3) Ada pengaruh positif motivasi kerja terhadap kinerja, dan (4) Ada pengaruh positif secara bersama-sama kepemimpinan partisipatif, budaya kerja, dan motivasi kerja terhadap kinerja pegawai.

\section{Metode}

Penelitian ini merupakan jenis penelitian survei dengan pendekatan kuantitatif deskriptif. Populasi penelitian ini adalah Pegawai Negeri Sipil (tenaga edukatif dan administrasi), dan mahasiswa semester VII di lingkungan Universitas Negeri Yogyakarta. Teknik sampling yang digunakan adalah proportionate srtatified random sampling. Penentuan jumlah sam- pel dalam penelitian ini dilakukan dengan menggunakan tabel Nomogram Herry King. Untuk populasi dosen 1043 orang, sampelnya 260 orang. Kemudian untuk populasi pegawai 589 orang, sampelnya 220 orang, dan untuk populasi mahasiswa semester VII sebanyak 5848 orang sampelnya 320 orang. Teknik pengumpulan data menggunakan angket, kemudian data dianalisis menggunakan model regresi sederhana dan ganda dengan bantuan sofware program SPSS.17.

\section{Hasil}

Sebelum analisis data, terlebih dahulu dilakukan uji normalitas, linieritas, heteroskedastisitas, dan uji multikolinieritas. Dari hasil uji yang dilakukan menunjukkan bahwa semua data telah memenuhi syarat untuk dilakukan uji hipotesis dengan menggunakan uji statistik. Adapun hasil uji statistik dapat dilihat pada Tabel 1.

Tabel 1. Rangkuman Hasil Uji Hipotesis

\begin{tabular}{cccccc}
\hline Variabel & Konstanta & $\begin{array}{c}\text { Koefisien } \\
\text { Regresi (b) }\end{array}$ & F & Sign. & R2 \\
Kepemimpinan Partisipatif & 20,128 & 0,476 & 149,816 & 0,000 & 0,419 \\
Budaya Kerja & 22,075 & 0,400 & 59,947 & 0,000 & 0,224 \\
Motivasi Kerja & 22,625 & 0,378 & 75,155 & 0,000 & 0,265 \\
\hline
\end{tabular}

Sumber: Data olahan SPSS

\section{Uji Hipotesis Pertama}

$\mathrm{H} 0$ : b1 = 0 (koefisien regresi $\mathrm{X} 1$ terhadap $\mathrm{Y}$ tidak signifikan)

Ha : b1 $\neq 0$ (koefisien regresi $X 1$ terhadap $Y$ signifikan)

Berdasarkan hasil analisis dari program SPSS.17, menunjukkan tingkat hubungan antara variabel $X_{1}$ terhadap $Y$ pada Pearson Correlation sebesar 0,419 atau $\left(\mathrm{rx}_{1} \mathrm{y}=0,419\right)$. Dengan nilai $\mathrm{rx}_{1} \mathrm{y}=0,419$ yang dihasilkan tersebut, maka dapat dikatakan bahwa pengaruh antara kepemimpinan partisipatif dengan kinerja tergolong "sedang". Nilai konstanta sebesar 20,128 bermakna bahwa apabila tidak ada perubahan gaya kepemimpinan, maka tingkat capaian kinerja adalah 20,128. Kemudian nilai koefisien regresi sebesar 0,419 bermakna bahwa gaya kepemimpinan dapat meningkatkan kinerja sebesar 0,419. Selanjutnya dari persamaan regresi dilakukan uji signifikansi pengaruh $X_{1}$ terhadap $Y$ dengan cara membandingkan nilai probabilitas $(p)$ dan tingkat signifikansi alpha $=$ 0,05 .

Berdasarkan hasil perhitungan, diperoleh persamaan regresi $X_{1}$ (Kepemimpinan partisipatif) terhadap $Y$ (Kinerja) adalah: $\mathrm{Y}=20,128+0,647 \mathrm{X}_{1}$. Untuk mengetahui signifikan tidaknya persamaan regresi tersebut dilihat dari Uji t. Apabila thitung lebih besar dari t-tabel, maka persamaan regresi tersebut signifikan. Dari hasil perhitungan diperoleh $t$-hitung $=149,816$; se- 
dangkan $\mathrm{t}_{\text {-tabel }}$ pada taraf signifikansi $\mathrm{p}<$ 0,05 dan $\mathrm{dk}=1 / 208$ diperoleh $\mathrm{t}_{\text {-tabel }} 3,84$. Dengan demikian terdapat pengaruh yang positif dan signifikan kepemimpinan terhadap kinerja pegawai UNY. Besarnya pengaruh kepemimpinan terhadap kinerja pegawai diperoleh dari nilai beta $=0,647$ sedangkan koefisien determinasinya $\left(\mathrm{rx}_{1} \mathrm{y}^{2}\right)$ diperoleh dari $R$ Square yakni sebesar 0,419. Hal tersebut berarti besarnya sumbangan kepemimpinan terhadap kinerja adalah $41,9 \%$ sedangkan sisanya $58,1 \%$ dipengaruhi oleh faktor lain.

\section{Uji Hipotesis Kedua}

$\mathrm{H} 0: \mathrm{b} 1=0$ (koefisien regresi $\mathrm{X} 2$ terhadap $\mathrm{Y}$ tidak signifikan)

Ha : b1 $\neq 0$ (koefisien regresi $X 2$ terhadap $Y$ signifikan)

Berdasarkan hasil analisis dari program SPSS.17, menunjukkan tingkat hubungan antara variabel $\mathrm{X}_{2}$ terhadap kinerja $\mathrm{Y}$ pada Pearson Correlation sebesar 0,224 atau $\left(\mathrm{rx}_{2} \mathrm{y}=0,224\right)$. Dengan nilai $\mathrm{rx}_{2} \mathrm{y}$ $=0,224$ yang dihasilkan tersebut, maka dapat dikatakan bahwa pengaruh antara budaya kerja dengan kinerja tergolong "rendah". Nilai konstanta sebesar 22,075 bermakna bahwa apabila tidak ada perubahan budya kerja, maka tingkat capaian kinerja adalah 22,075. Kemudian nilai koefisien regresi sebesar 0,400 bermakna bahwa budaya kerja dapat meningkatkan kinerja sebesar 0,400 . Selanjutnya dari persamaan regresi dilakukan uji signifikansi pengaruh $\mathrm{X}_{2}$ terhadap $\mathrm{Y}$ dengan cara membandingkan nilai probabilitas $(p)$ dan tingkat signifikansi alpha $=0,05$.

Berdasarkan hasil perhitungan, diperoleh persamaan regresi $X_{2}$ (Budaya Kerja) terhadap $\mathrm{Y}$ (Kinerja) adalah: $\mathrm{Y}=$ $22,075+0,473 \mathrm{X}_{2}$. Untuk mengetahui signifikan tidaknya persamaan regresi tersebut dilihat dari Uji t. Apabila t-hitung lebih besar dari $t$-tabel, maka persamaan regresi tersebut signifikan. Berdasarkan hasil perhitungan diperoleh t-hitung $=59,947$; sedangkan $\mathrm{t}_{\text {-tabel }}$ pada taraf signifikansi $\mathrm{p}<0,05$ dan $\mathrm{dk}=1 / 208$ diperoleh 3,84. Dengan demikian dapat dinyatakan bahwa koefisi- en regresi signifikan. Dengan kata lain, terdapat pengaruh yang positif dan signifikan budaya kerja terhadap kinerja pegawai UNY. Besarnya pengaruh budaya kerja terhadap kinerja pegawai diperoleh dari nilai beta $=0,473$ sedangkan koefisien determinasinya $\left(\mathrm{rx}_{2} \mathrm{y}^{2}\right)$ diperoleh dari $R$ Square yakni sebesar 0,224. Hal tersebut berarti besarnya sumbangan budaya karja terhadap kinerja adalah 22,4\% sedangkan sisanya $77,6 \%$ dipengaruhi oleh faktor lain.

\section{Uji Hipotesis Ketiga}

$\mathrm{H}_{0}: \mathrm{b}_{1}=0$ (koefisien regresi $\mathrm{X}_{3}$ terhadap $\mathrm{Y}$ tidak signifikan)

$\mathrm{H}_{\mathrm{a}}: \mathrm{b}_{1} \neq 0$ (koefisien regresi $\mathrm{X}_{3}$ terhadap $\mathrm{Y}$ signifikan)

Berdasarkan hasil analisis dari program SPSS, menunjukkan tingkat hubungan antara variabel $X_{3}$ terhadap kinerja $Y$ pada Pearson Correlation sebesar 0,265 atau $\left(\mathrm{rx}_{3} \mathrm{y}=0,265\right)$. Dengan nilai $\mathrm{rx}_{3} \mathrm{y}=0,265$ yang dihasilkan tersebut, maka dapat dikatakan bahwa hubungan antara motivasi kerja dengan kinerja tergolong "rendah".

Berdasarkan hasil perhitungan, diperoleh persamaan regresi $X_{3}$ (Motivasi Kerja) terhadap $\mathrm{Y}$ (Kinerja) adalah: $\mathrm{Y}=$ $22,625+0,515 X_{3}$. Untuk mengetahui signifikan tidaknya persamaan regresi tersebut dilihat dari Uji t. Apabila t-hitung lebih besar dari $t$-tabel, maka persamaan regresi tersebut signifikan. Berdasarkan hasil perhitungan diperoleh $\mathrm{t}$-hitung $=75,155$; sedangkan $\mathrm{t}$-tabel pada taraf signifikansi $\mathrm{p}<0,05 \mathrm{dan} \mathrm{dk}=$ 1/208 diperoleh 3,84. Dengan demikian dapat dinyatakan bahwa koefisien regresi signifikan. Dengan kata lain, terdapat pengaruh yang positif dan signifikan budaya kerja terhadap kinerja pegawai UNY. Besarnya pengaruh motivasi kerja terhadap kinerja pegawai diperoleh dari nilai beta $=0,515$ sedangkan koefisien determinasinya $\left(\mathrm{rx}_{3} \mathrm{y}^{2}\right)$ diperoleh dari $R$ Square yakni sebesar 0,265 . Hal tersebut berarti besarnya sumbangan kepemimpinan terhadap kinerja adalah $26,5 \%$ sedangkan sisanya $73,5 \%$ dipengaruhi oleh faktor lain. 


\section{Uji Hipotesis Keempat}

$\mathrm{H} 0: \mathrm{b} 1=0$ (koefisien regresi $\mathrm{X} 1 \mathrm{X}_{2} \mathrm{X} 3$ terhadap $Y$ tidak signifikan)

Ha : b1 $\neq 0$ (koefisien regresi X1 X2 X3 terhadap Y signifikan)

Berdasarkan hasil analisis dari program SPSS, menunjukkan tingkat hubungan antara variabel $\mathrm{X}_{3}$ terhadap kinerja $\mathrm{Y}$ pada Pearson Correlation sebesar 0,589 atau ( $\mathrm{rx}_{1}$ $\left.\mathrm{rx}_{2} \mathrm{rx}_{3} \mathrm{y}=0,589\right)$. Dengan nilai $\mathrm{rx}_{1}, \mathrm{rx}_{2}, \mathrm{rx}_{3} \mathrm{y}$ $=0,589$ yang dihasilkan tersebut, maka dapat dikatakan bahwa secara bersamasama hubungan antara kepemimpinan, budaya kerja, dan motivasi kerja dengan kinerja tergolong "sedang". Untuk menguji hipotesis pengaruh variabel bebas dan terikat serta sumbangan pada tiap variabel bebasnya terhadap variabel terikat, digunakan teknik analisis regresi sederhana dan regresi ganda menggunakan SPSS 17.0 Dalam pengujian ini menggunakan kriteria penerimaan dan penolakan tingkat signifykansi 5\% dengan ketentuan signifikansi $p<$ 0,05 . Hasil analisis regresi ganda diperoleh besarnya pengaruh tiap-tiap variabel bebas terhadap variabel terikat disajikan pada Tabel 2.

Tabel 2. Rangkuman Hasil Analisis Regresi

\begin{tabular}{cccccc}
\hline Variabel & Beta & $\mathrm{t}$ & Sig & $\mathrm{r}$ parsial & Kesimpulan \\
\hline X1-Y & 0,339 & 9,388 & 0,000 & 0,419 & Signifikan \\
X2-Y & 0,244 & 6,167 & 0,000 & 0,224 & Signifikan \\
X3-Y & 0,220 & 6,261 & 0,000 & 0,265 & Signifikan \\
\hline
\end{tabular}

Sumber: Data olahan SPSS

Berdasarkan hasil perhitungan SPSS. 17 seperti ditunjukkan pada Tabel 2 di atas, maka diperoleh persamaan regresi variabel $\mathrm{X}_{1} \mathrm{X}_{2} \mathrm{X}_{3}$ terhadap $\mathrm{Y}$ adalah: $\mathrm{Y}=$ $5,428+0,399 X_{1}+0,244 X_{2}+0,220 X_{3}+$ e. Berdasarkan hasil perhitungan diperoleh $\mathrm{F}$ hitung $=98,432$; sedangkan $\mathrm{F}_{\text {-tabel }}$ pada taraf signifikansi $\mathrm{p}<0,05$ dan $\mathrm{dk}=3 / 206$ diperoleh 2,60. Dengan demikian dapat dinyatakan bahwa koefisien regresi signifikan. Dengan kata lain, terdapat pengaruh yang positif dan signifikan kepemimpinan dan budaya kerja terhadap kinerja pegawai UNY. Besarnya pengaruh kepemimpinan dan budaya kerja terhadap kinerja pegawai diperoleh dari $R^{2}(R$ Square) yakni sebesar 0,589 . Hal tersebut berarti besarnya sumbangan kepemimpinan partisipatif dan budaya kerja terhadap kinerja adalah 58,9\% sedangkan sisanya $41,1 \%$ dipengaruhi oleh faktor lain.

\section{Pembahasan}

Berdasarkan deskripsi data penelitian dan pengujian hipotesis, akan dilakukan pembahasan hasil sesuai dengan tujuan penelitian yaitu untuk mengetahui ada tidaknya pengaruh variabel: (1) kepemimpinan partisipatif terhadap kinerja, (2) budaya kerja terhadap kinerja, (3) motivasi kerja terhadap kinerja, dan (4) secara bersama-sama kepemimpinan partisipatif, budaya kerja, dan motivasi kerja terhadap kinerja akan diuraikan di bawah ini.

\section{Pengaruh Kepemimpinan terhadap Kinerja}

Kepemimpinan merupakan aktivitas yang melibatkan tiga variabel penting yakni pemimpin itu sendiri, pengikut, dan situasi (Hughes, Ginnett \& Curphy, 2006, p.6). Pemimpin yang sukses adalah pemimpin yang mampu mengelola potensi yang dimiliki oleh para pengikut dan membiarkannya tumbuh berkembang dalam situasi yang kondusif di bawah pengawasan serta arahan pemimpinnya. Kepemimpinan yang sukses dalam suatu organisasi sangat ditentukan oleh tipe/gaya pemimpinnya dalam meningkatkan kinerja individu dan organisasi.

Hasil analisis menunjukkan bahwa kepemimpinan partisipatif berpengaruh secara positif dan signifikan terhadap kinerja pegawai di UNY. Dari hasil analisis 
korelasi diperoleh nilai $R=0,647$ pada $\mathrm{p}<$ 0,05 , artinya hubungan antara variabel kepemimpinan dengan kinerja termasuk dalam kategori tinggi dan signifikan. Kemudian dari hasil analisis regresi sederhana juga diperoleh nilai koefisien regresi ke arah positif sebesar 0,419 dengan konstanta sebesar 20,128 pada taraf signifikansi $\mathrm{p}<0,05$. Dengan demikian dapat disimpulkan bahwa kepemimpinan memberi pengaruh yang positif dan signifikan terhadap kinerja pegawai UNY. Hal ini ditunjukkan dengan besarnya angka sumbangan sebesar 41,9.\% terhadap kinerja pegawai UNY. Adapun persamaan yang dihasilkan adalah $\mathrm{Y}=20,128+0,647 \mathrm{X}_{1}$.

Berdasarkan persamaan model regresi sederhana di atas, maka dapat dimaknai bahwa semakin baik dalam praktik kepemimpinan dari seorang pemimpin akan diikuti oleh meningkatnya kinerja pegawai. Sumbangan kepemimpinan terhadap kinerja sebasar $41,9 \%$ berarti bahwa kepemimpinan memiliki sumbangan dalam usaha meningkatkan kinerja pegawai.

\section{Pengaruh Budaya Kerja terhadap Kinerja}

Budaya organisasi merupakan kumpulan nilai-nilai (values), sikap, keyakinan (beliefs), dan norma bersama secara tersembunyi maupun terang-terangan. Keyakinan, norma, dan nilai-nilai tersebut pada umumnya telah lama berlaku untuk disepakati dan diikuti oleh para anggota suatu organisasi sebagai pedoman dalam pemecahan masalah. Dengan demikian tidak ada masalah dalam organisasi yang tidak bisa diselesaikan apabila selalu memegang teguh budaya organisasi yang disepekati bersama. Semakin jelas bahwa budaya berguna sebagai pemersatu dan perekat antaranggota dalam mencapai tujuan organisasi. Budaya kerja yang dibangun dan dibentuk melalui lingkungan kerja yang kondusif akan membantu kelancaran tugas yang dilakukan oleh para pegawai. Tugas-tugas dan tanggung jawab yang dikerjakan secara baik, tepat waktu, penuh tanggung jawab, dan persahabatan dari para pegawai akan membantu me- ningkatkan capaian kinerja yang diharapkan.

Hasil analisis menunjukkan bahwa budaya kerja berpengaruh secara positif dan signifikan terhadap kinerja pegawai di UNY. Dari hasil analisis korelasi diperoleh nilai $R=0,473$ pada $\mathrm{p}<0,05$, artinya hubungan antara variabel budaya kerja dengan kinerja termasuk dalam kategori sedang dan signifikan. Kemudian dari hasil analisis regresi sederhana juga diperoleh nilai koefisien regresi ke arah positif sebesar 0,224 dengan konstanta sebesar 22,075 pada taraf signifikansi $\mathrm{p}<0,05$. Dengan demikian dapat disimpulkan bahwa budaya kerja memberi pengaruh yang positif dan signifikan terhadap kinerja pegawai UNY. Hal ini ditunjukkan dengan besarnya angka sumbangan sebesar 22,4\% terhadap kinerja pegawai UNY. Adapun persamaan yang dihasilkan adalah $\mathrm{Y}=$ $22,075+0,473 X_{2}$.

Berdasarkan persamaan model regresi sederhana di atas, maka dapat dimaknai bahwa semakin baik budaya kerja yang berlaku di lingkungan kerja akan diikuti oleh meningkatnya kinerja pegawai. Sumbangan budaya kerja terhadap kinerja sebasar 22,4. \% berarti bahwa budaya kerja memiliki sumbangan dalam usaha meningkatkan kinerja pegawai.

\section{Pengaruh Motivasi Kerja terhadap Kinerja}

Motivasi adalah keinginan untuk berbuat sesuatu, sedangkan motif adalah kebutuhan (need), keinginan (wish), dan dorongan (desire/impulse), (Husaini Usman, 2011, p.250). Masih menurut Husaini Usman, bahwa motivasi merupakan keinginan yang terdapat pada seseorang individu yang merangsangnya untuk melakukan tindakan-tindakan atau sesuatu yang menjadi dasar atau alasan seseorang berperilaku. Sedangkan motivasi kerja dapat diartikan sebagai keinginan atau kebutuhan yang menjadi sebab seseorang bekerja.

Hasil analisis menunjukkan bahwa motivasi kerja berpengaruh secara positif dan signifikan terhadap kinerja pegawai di UNY. Dari hasil analisis korelasi diperoleh 
nilai $R=0,515$ pada $\mathrm{p}<0,05$, artinya hubungan antara variabel motivasi kerja dengan kinerja termasuk dalam kategori rendah namun signifikan. Kemudian dari hasil analisis regresi sederhana juga diperoleh nilai koefisien regresi ke arah positif sebesar 0,265 dengan konstanta sebesar 22,625 pada taraf signifikansi $\mathrm{p}<0,05$. Dengan demikian dapat disimpulkan bahwa budaya kerja memberi pengaruh yang positif dan signifikan terhadap kinerja pegawai UNY. Hal ini ditunjukkan dengan besarnya angka sumbangan sebesar 26,5\% terhadap kinerja pegawai UNY. Adapun persamaan yang dihasilkan adalah $\mathrm{Y}=$ $22,625+0,378 X_{3}$.

Berdasarkan persamaan model regresi sederhana di atas, maka dapat dimaknai bahwa semakin tinggi motivasi kerja para pegawai akan diikuti oleh meningkatnya kinerja pegawai. Sumbangan motivasi kerja terhadap kinerja sebasar 26,5\% berarti bahwa motivasi kerja memiliki sumbangan/andil dalam usaha meningkatkan kinerja pegawai.

Pengaruh Kepemimpinan Partisipatif, Budaya Kerja, dan Motivasi Kerja terhadap Kinerja

Peranan pemimpin dalam praktik organisasi sangat menentukan tinggi rendahnya kinerja pegawai. Dengan model dan gaya kepemimpinan tertentu seorang pemimpin mampu membangun komitmen orang-orang yang dipimpinnya agar menghasilkan kinerja yang optimal. Akan tetapi banyak juga pemimpin yang gagal dalam meraih kinerja organisasi secara optimal karena kesalahan dan ketidakmampuan dalam menerapkan modelmodel kepemimpinan yang dibangun dan diterapkan kepada para bawahan. Kemampuan upaya seseorang dalam mewujudkan keinginan atau tujuan sebagai usaha memenuhi kebutuhan hanya akan berhasil apabila upaya sebagai ukuran intensitas tersebut terus ditingkatkan.

Hasil analisis menunjukkan bahwa secara bersama-sama kepemimpinan partisipatif, budaya kerja, dan motivasi kerja berpengaruh positif dan signifikan terhadap kinerja pegawai di UNY. Dari hasil analisis korelasi diperoleh nilai $R=0,768$ pada $\mathrm{p}<0,05$, artinya hubungan antara variabel budaya kerja dengan kinerja termasuk dalam kategori sedang dan signifikan. Kemudian dari hasil analisis regresi sederhana juga diperoleh nilai koefisien regresi ke arah positif sebesar 0,589 dengan konstanta sebesar 5,428 pada taraf signifikansi $p<0,05$.

Dengan demikian dapat disimpulkan bahwa secara bersama-sama kepemimpinan partisipatif, budaya kerja, dan motivasi kerja memberi pengaruh yang positif dan signifikan terhadap kinerja pegawai UNY. Hal ini ditunjukkan dengan besarnya angka sumbangan sebesar 58,9\% terhadap kinerja pegawai UNY. Adapun persamaan yang dihasilkan adalah $Y=5,428+0,399 X_{1}$ $+0,244 X_{2}+0,220 X_{3}+e$.

Dari hasil persamaan model regresi ganda di atas, dapat dimaknai bahwa kepemimpinan partisipatif yang dijalankan, budaya kerja yang dianut, dan motivasi kerja yang tinggi akan diikuti meningkatnya kinerja pegawai. Sumbangan kepemimpinan partisipatif, budaya kerja, dan motivasi kerja terhadap kinerja sebesar $58,9 \%$ yang berarti bahwa ketiga variabel tersebut memiliki sumbangan yang signifikan dalam usaha meningkatkan kinerja pegawai.

Berdasarkan hasil pembuktian hipotesis dan pembahasan di atas, maka secara singkat dapat disimpulkan bahwa gaya kepemimpian partisipatif yang diterapkan oleh para pimpinan di UNY dapat memengaruhi kinerja pegawai. Begitu pula dengan budaya kerja yang ada dan berlaku di setiap fakultas dan unit kerja di UNY dapat memengaruhi kinerja pegawai. Selain itu motivasi kerja pegawai juga memiliki sumbangan yang positif dalam meningkatkan kinerja baik secara individual maupun organisasional.

\section{Simpulan}

Dari hasil analisis data dan pembahasan, maka dapat disimpulkan bahwa 
(1) Terbukti ada pengaruh positif dan signifikan kepemimpinan partisipatif terhadap kinerja pegawai UNY, yang ditunjukkan dengan angka pengaruh antara kedua variabel tersebut yakni besaran angka $R^{2}=0,419 ; t=9,388 ; p<0,05$. (2) Terbukti ada pengaruh positif dan signifikan budaya kerja terhadap kinerja pegawai UNY, yang ditunjukkan dengan angka pengaruh antara kedua variabel tersebut yakni besaran angka $\mathrm{R}^{2}=0,224 ; \mathrm{t}=$ 6,167; $p<0,05$. (3) Ter-bukti ada pengaruh positif dan signifikan motivasi kerja terhadap kinerja pegawai UNY, yang ditunjukkan dengan besaran angka $\mathrm{R}^{2}=0,265$; $\mathrm{t}$ $=6,261 ; p<0,05$. (4) Ada pengaruh positif dan signifikan secara bersama-sama kepemimpinan partisipatif, budaya kerja, dan motivasi kerja terhadap kinerja pegawai UNY. Besarnya angka pengaruh tiga variabel tersebut terhadap kinerja ditunjukkan oleh angka $R^{2}=0,589 ; F=98,43 ; p<0,05$. Hal tersebut berarti besar-nya sumbangan kepemimpinan partisipatif, budaya kerja, dan motivasi kerja terhadap kinerja tergolong "sedang" yakni sebesar 58,9\% adapun sisanya $41,1 \%$ dipengaruhi oleh faktor lain.

\section{Saran}

Berdasarkan kesimpulan hasil penelitian, maka beberapa saran yang bisa dajukan yaitu: (1) Oleh karena kepemimpinan merupakan faktor yang paling tinggi pengaruhnya terhadap kinerja pegawai, maka hendaknya para pemimpin dalam proses pembuatan keputusan menerapkan gaya kepemimpinan yang cocok dengan kondisi para pegawai. (2) Budaya kerja sebagai perekat antarpegawai perlu dijaga, dikembangkan, dan diperkuat melalui praktik kepemimpinan agar dapat meningkatkan kinerja para pegawai. (3) Motivasi kerja pegawai masih perlu ditingkatkan agar kinerjanya juga bisa ditingkatkan. Peningkatan kinerja dapat dilakukan dengan cara menanamkan nilai-nilai kejujuran, kesantunan, kesopanan, kejujuran, dan tanggung jawab dalam bekerja. Peningkatan kinerja dapat dilakukan dengan membuat target kepada para pegawai untuk dicapai dalam kurun waktu tertentu sesuai. (4) Hasil penelitian ini diharapkan bisa dipakai sebagai bahan pertimbangan dalam pengambilan keputusan menyangkut kepemimpinan, budaya kerja, dan kinerja pegawai.

\section{Daftar Pustaka}

Bass, M, Bernard. (2008). The bass handbook of leadership (theory, research, \& managerial applications). New York: Free Press.

Beerel, Annabel. (2010). Leadership and change management. Los Angeles: SAGE.

Hoy, Wayne K. \& Miskel, Cecil G. (2008). Educational administration, theory, research, and practice, ( $8^{\text {th }}$ ed). New York: Mcgraw Hill.

Hughes, Richard.L, Ginnett, Robert.C, Curphy, Gordon.J. (2006). Leadership: enhancing the lessons of experience, (5 $5^{\text {th }}$ ed). New York: Mc Graw Hill.

Pabundu Tika. (2006). Budaya organisasi dan peningkatan kinerja perusahaan. Cetakan pertama. Jakarta: Bumi Aksara.

Robins, Stephen P. (2001). Organizational behavior, $\left(9^{\text {th }}\right.$ ed). Prentice-Hall: International Inc.

Sashkin, Marshall \& Sashkin, Molly, G. (2011). Prinsip-prinsip kepemimpinan. Jakarta: Erlangga.

Sinambela, Poltak, L. (2012). Kinerja pegawai (teori pengukuran dan im-plikasi). Yogyakarta: Graha Ilmu.

Sudarmanto. (2009). Kinerja dan pengembangan kompetensi SDM: teori, dimensi, pengukuran, dan implementasi dalam organisasi. Cetakan pertama. Yogyakarta: Pustaka Pelajar.

Sugiyono. (2011). Metode penelitian kombinasi (mixed methods). Bandung: Alfabeta. 
Veithzal Rivai \& Ella Jauvani Sagala. (2011). Manajemen sumber daya manusia untuk perusahaan (teori dan praktik), (ed.2). Jakarta: Rajawali Press.
Wibowo. (2012). Manajemen kinerja. Cetakan keenam, (ed.3). Jakarta: PT. Raja Grafindo Persada.

Yukl, Gary. (2006). Leadership in organization, (6 th $^{\text {th }}$ ). New Jersey: PrenticeHall. 